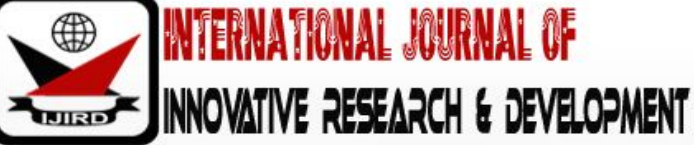

ISSN 2278 - 0211 (Online)

\section{Africa's Path to Growth and Sustainable Development: African \\ Universities' Collaborative Research in Technological Innovations, Utilization of Local Content Materials in the Production of Technological and Other Goods and Consumption of Locally-Made Goods}

Osakpa, David U
Lecturer, Department of Social Science Education, Imo State University, Owerri, Nigeria
Okonkwo, Dyke A. R
Lecturer, Department of OTM, Federal Polytechnic, Owerri, Nigeria
Adzei, Kofi Semanu Atsu
Lecturer, Kwabena Nketia Center for Africana Studies,
African University College of Communications, Accra, Ghana
Lebo, Monica P
Ejiogu, Stella I
Lecturer, Department of Business Management, University of Calabar, Calabar, Nigeria
Lecturer, Department of Physical Science Education, Imo State University, Owerri, Nigeria
Dr. Beshel, Justin Atiang
Lecturer, Department of Physiology, Kampala International University, Western Campus, Uganda
Abeh, David A
Lecturer, Department of Civil Engineering, Cross River University of Technology, Calabar, Nigeria

\begin{abstract}
:
This paper investigated Africa's path to growth and sustainable development: universities' collaborative research in technological innovations, utilization of local content in the production of technological and other goods and consumption of locally-made goods. The objective was to ascertain the relationship between African universities' collaborative research in technological innovations, utilization of local content materials in the production of technological and other goods and consumption of locally-made goods as a significant path to the continent's growth and sustainable development. The choice of this topic was justified because of its relevance to the current global emphasis on knowledge economy, skills acquisition and entrepreneurship. A survey design was adopted for the study. The population was made up of 15,000 university lecturers drawn from six universities and one polytechnic across the continent out of which a sample of 480 was identified based on cluster sampling. Four null hypotheses were formulated to guide the study. A sixteen-item four-point rating scale was constructed and administered on the sample for data collection. Data gathered were tested with the t-test and ANOVA at $p>$ 0.05 to ascertain the relationship between the variables. The paper found that there was a significant relationship between the variables under investigation. Based on this finding, it was concluded that there wasa significant relationship between African universities' collaborative research in technological innovations, utilization of local content materials in the production of technological and other goods, Africans' consumption of locally-made goods and Africa's path to growth and sustainable development. Three recommendations were made one of which was that a Pan-African Universities' Research Team in Technological Innovations should be established as soon as possible in the continent.
\end{abstract}

Keywords: Africa Universities, collaborative research, innovations, goods, sustainable development

\section{Introduction}

This paper was not written to bemoan the backwardness and underdevelopment of Africa and hold Europeans responsible for the prevailing situation in the continent (Rodney, 1972; Agbo, 2012). Rather, it was a soul-searching discourse to identify what Africans have done to keep themselves under bondage (Igwe, 2010; Meredith, 2011) and neglected to do(Garba, 1987; Guest, 2004) to extricate themselves from the vice grip of neo-colonialism, underdevelopment and lack of a sustainable development ideology (Okonkwo, Ejiogu \& Osakpa, 2017). This paper places Africans in proper perspective to assess the predicament of the continent and its people (Ashimolowo, 2007; Clarke, 2008; Morris, 2011).Since the fall of apartheid, the last vestige of slave trade and colonialism in Africa, the challenge of growth 
and sustainable development has stalked the continent and its people. Agreat deal has been discussed on this challenge between individual Africans, national, continental and international foras. Since the 1980s, Africa has been searching for a path to growth and sustainable development (Nwankwo, Chababaghi \& Boyd, 2009; Appiah \& Azeez, 2016 and Akinbami, Ifeanyi-Obi, Appiah \& Kabo-Bah, 2016, etc). The question: Is Africa marooned in Robinson Crusoe's "island of backwardness and underdevelopment"?What may Africans do to put themselves together and get the act right? This is the challengethese researchers decided to beam their searchlight in the direction of African universities' collaborative research in technological innovation, utilization of local content materials in the production of technological and other goods and Africans' consumption of locally-made goods. The Chinese saying that "it does not matter how long one has been doing something wrongly; as soon as a better way is found for doing it, that person should begin doing it right" is instructive.

African universities' collaborative research in technological innovations means a number of African universities come together to identify a technological problem, brainstorm on it and devise innovative techniques to solve it by inventing or modifying (innovating) an existing piece of machinery or technique. Utilization of local content materials in the production of either technological or other goods needs not be over-flogged. Africa abounds with creative and inventive minds (Forsyth, 1977) as well as a wide variety of raw materials that are a craze among developed countries (Peacock, 1982). It is no gainsaying the fact that why Africa was colonized and shared among European powers in 1844 at the Berlin Conference was the discovery of an abundance of raw materials and possibly the remote cause of the First and Second World Wars (Peacock, 1982).These are the raw materials that developed countries exploit, take home at almost give-away prices and manufacture finished goods that Africans buy at exorbitant prices! Why is it that African universities cannotutilize these materials for the production of locally-made goods? Africans' consumption of locally-made goods means they (Africans) take pride in using technological or other goods made locally no matter how crude these may be. This consumption attitude has the effect of keeping local industries in production, improving local technology and quality of the goods as well as creating job opportunities for Africans. This is why this paperar gues that the path to Africa's growth and sustainable development is for African universities to conduct collaborative researches in technological innovations, utilize local content materials in the production of technological or other goods and for Africans to consume locally-made goods. Consequently, the following null hypotheses were formulated to guide the study and tested at $p>0.05$ alpha level:

- $\mathrm{H}_{0} 1$ : There is no significant relationship between African universities' collaborative research in technological innovations and Africa's path to growth and sustainable development.

- $\mathrm{H}_{0} 2$ : Utilization of local content materials in the production of technological and other goods has no significant relationship with Africa's path to growth and sustainable development.

- $\mathrm{H}_{0} 3$ : Africans' consumption of locally-made goods has no significant relationship with the continent's path to growth and sustainable development.

- $\mathrm{H}_{0}$ 4:African universities' collaborative research in technological innovations, utilization of local content materials in the production of technological and other goods, Africans' consumption of locally-made technological goods and Africa's path to growth and sustainable development have no significant relationship.

\section{Literature Review}

Relevant secondary materials were reviewed under the following four variables: Africa's path to growth and sustainable development, African universities' collaborative research in technological innovations, utilization of local content materials in the production of technological and other goods and Africans' consumption of locally-made goods.

\subsection{Africa's Path to Growth and Sustainable Development}

In this paper, Africa's path to growth and sustainable development is defined as a better way through which the continent can grow scientifically, technologically, economically, socially, and politically such that these indices become regenerative development processes among Africans. This means these indices become living characteristics among Africans and replicate themselves as a natural course of happening; without conscious efforts. However, several approaches to growth and sustainable development have been taken by individual African countries and the continent as a body (Ahenkan \& Osei-Kojo, 2014; Lundvall \& Lema, 2014). Bilateral trade and economic agreements exist between countries, structural adjustment programmes have been initiated and implemented across the continent (Abdulrahman, 2008); the bait of foreign direct investments (Williams \& Williams, 1999-xxii); the wishy-washy benefits of dependence on developed countries (dos Santos, 1993); sustainable debt and development strategy in Africa (Enweze, 2003); external debt, capital inflows and growth in Nigeria (Ajayi, 2003), international aid and debt strategies: implications for Nigeria (Collier, 2003) and inclusive growth, human capital development and natural resource rent in Sub-Saharan Africa's: economic change and restructuring, Raheem, Isah, \& Adedeji, (2018).

Africa has found it difficult to chart a viable path to growth and sustainable development because no country in the continent can escape the web of relationships spun with Europe since the fifteenth century (Garba, 1987). For example, in 1844 at the Berlin Conference, Africa was treated like cattle amassed over a large field chewing grass while merchants bargained over their heads; the entire continent slept, farmed, sang, danced and attended to their numerous gods and deities while they were shared in the country mansions and palaces of European kings (Agbo, 2012). This is why even after political independence; there have been pervasive and amorphous psychological ties between African countries and their erstwhile colonial masters that produce varied but often unpredictable response in polices. What is more: Britain could limit her former colonies' contacts with other countries whether in Western or Eastern Europe or North America. 
Britain had in its own interest, prevented economic penetration from other countries (Garba, op. cit.). Developed countries still fix prices of Africa's raw materials at will at the World Trade Organization (WTO).

Other research studies reviewed on this unit included: Udeozor \& Mbagwu (2012) who concluded that it is only creative invention and innovation that can propel Nigeria on to the path of sustainable entrepreneurial status. Chukwumezie, Osakpa \& Okonkwo (2016) concluded that sustainable development in Nigeria and the rest of Africa was based on the adoption of pragmatic business management strategies, capital formation and government's provision of real political goods as analyzed by Almond, et al ((2004). Bisson (2017) found that there was a lack of research on sustainable development in Sub-Saharan Africa (SSA) but, however, argues that the region stands to enjoy high levels of growth by attracting foreign direct investment. Babyenda (2017) found that foreign direct investment had no impact on Uganda's economic growth and Ngwenya, (2015) argues that 55 years after independence, Nigeria had no definite industrial development policy, its economic and integrated development efforts epileptic, educational system; wishy-washy and women entrepreneurs not properly organized and supported for effective contribution to the economic development of the country. Bremer \& López-Franco (2006) concluded that during the last ten years, the SD course evolved through several teaching techniques, methods and platforms from a traditional classroom to a distant teaching/ learning, up to an on-line course. They argued further that the most important changes have been the content and the impact of the course upon the personal and professional lives of the students although initially it was mostly an informative course about the most important environmental issues and their social and economic consequences. Nwankwo, Chahabaghi \& Boyd (2009) found that the orthodox knowledge of sustainable development (SD) reflects axioms that are inextricably linked to the idiosyncrasies of the developed world, framed in opinions, languages and meanings that are poorly communicated and understood by rural Africa. As a result, many African countries remain bystanders in this important global discourse. However, Africa stands to benefit from China's experience of trade reforms and opening up of its markets (Pingjan, 2018).

In summary, if the paths and development strategies Africa had used failed to take the continent to the Promised Land, there are no other options than to follow the example of China and the PAFTAD 20 in addition to the bilateral and regional development strategies enunciated in the continent after the fall of colonialism and apartheid. Of particular interest are those development programmes articulated by the AU (African Union). Luckily for the continent, it can explore and exploit the opportunities offered by the BRICS (Brazil, Russia, India, China and South Africa) economic, scientific, and technological and development bloc.

The researchers, therefore, argue that if Africa adopts the following simple model, it will be on its way to growth and sustainable development.

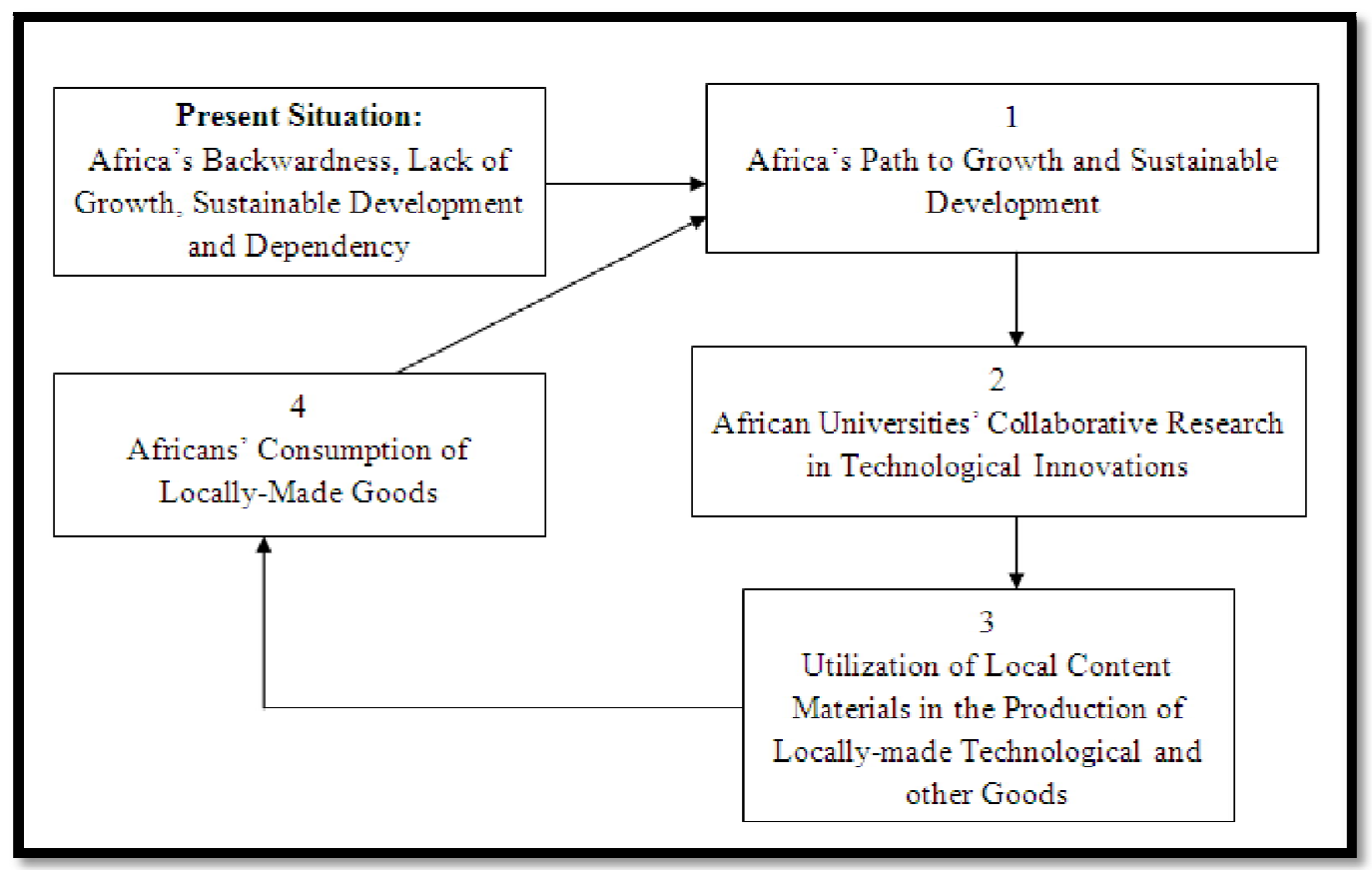

Figure 1: Model on Africa's Path to Growth and Sustainable Development

This simple model is a compressed sequence of activities that African countries may adopt or adapt to implement the variables argued in this paper for actualizing growth and sustainable development in the continent.

\subsection{African Universities' Collaborative Research in Technological Innovations}

The coming together of African universities to identify a technological problem and conduct research to solve it means such universities collaborate in technological innovation research. Hammajam, Mairo \& Usman (2016) found that the establishment of Technology Incubation Centers (TICs) across Nigeria was a welcome policy for industrial development that brings together universities, polytechnics and the private sector into a partnership for economic and technological development. Awe, Olawale \& Bola (2016) found that building strategic technical partnerships with cooperator ventures and capital provide necessary solutions to the problems of industrial development and competitiveness among Nigerian entrepreneurs. Okonkwo, Ejiogu \& Osakpa (2017) found that Africa needed to cultivate 
and amass intellectual capital and modernize its economy to knowledge economy by exploiting global markets, open economy and working with major technological partners in locally fabricating technical equipment for industrialization. Opolot-Okurut \& Bbuye (2014) found that there were merits and demerits in university-school partnerships with increased need for university and school administrators to support school teachers' benefits from the collaboration. Protsiv, Rosales-Klintz, Bwanga, Zwarenstein \& Atkins (2016) found that technology aided teaching approaches, skills as blended learning (BL) can stimulate international education collaboration and connect skilled scientists who can jointly contribute to the efforts to address local shortages of high-level research capacity. Mensah, Enu-Kwesi \& Boohene (2017) found that collective assets (values and trust); structural and positional factors(limited funding and inadequate infrastructure) were key challenges of research collaboration that lead to a clash of values between academics and knowledge users. The result was an absence of comprehensive national and institutional support for research collaboration. Morrison, Dobbie \& McDonald (2013) findings supported the sociology of science model of vertical collaboration although at present, there is a horizontal collaboration. Fari (2015) found that research collaboration does occur among academics/researchers in the universities. South Africa collaborated more, but country-wise, Nigeria had more domestic collaborations. Bogoro (2015) argued that the Federal University of Technology, Owerri (FUTO) is not just a University of Technology but has, indeed, earned its name through ground-breaking research outputs, commercialized and commercializable research breakthroughs and penetration of the Nigerian economy with many industry-relevant patents; that FUTO was deliberately located in the South East, the heartland of Nigeria's innovations and technological breakthroughs especially at a time the country was aggressively pursuing $R \& D$ in shaping the competency of our tertiary institutions: Universities of Technology and Polytechnics. Makoni (2011) found that the French language has become a common driver for technological innovation among French-speaking technology universities.

However, Obanor \& Kwasi-Effah (2013) found that there was no collaboration between universities and industries in North Central, South-South and South West regions of Nigeria. Canho to \& Quinton (2016) found that research collaboration was beneficial when: (1) information is shared in ways that are accessible and relevant to the other party, (2) discrepancies in modes of operation/ interest in establishing a common language are identified, (3) third-party brokers are leveraged, (4) trust through small wins and regular interactions are developed and (5) teams with common attitudes and complementary skills are assembled.

Another important factor is that of linkages between industry and universities. These linkages should be in the form of partnerships in which mutual support for specific programs can be identified and implemented. For instance, some of the R\&D activities of local industries could be hosted at universities or research institutes and financed mostly by these industries. This would certainly ease the financial burden of the universities and research institutes occasioned by the heavy funding needed to equip some of their research laboratories: industrial chairs, internships, joint research programs, sandwich degree programs and sharing of laboratory facilities/ infrastructure.

These partnership components will create a positive environment that encourages researchers to form interest groups to aid in interaction and interpretation of research in the context of enhancing education and production. A key component of this environment is the creation of multiple industrial chairs or joint appointments. Other issues need to be addressed in this context and include the promotion of local industry and economy, provision of technical assistance to existing small and medium enterprises (SMEs), and promotion of the creation of new SMEs.

\subsection{Utilization of Local Content Materialsin the Production of Technological Goods}

This means African universities research into the use of materials that abound in the continent to manufacture technological and other goods. Esteves, Coyne \& Moreno (2013) define what constitutes local content as a workforce, supply chain, local procurement, locally owned or at extremes, simply any business that maintains a permanent operational office within a given area. Local content also defined as the value contributed to the national economy through purchase of national goods and services. They further argue that "Local value-added" is the wealth local companies create in transforming materials and services purchased from other countries into revenue-generating output. Siyanbola, Adeyeye, Olaopa \&Hassan (2016) argue that the process of formulating science, technology and innovation (STI) policy in Nigeria using scientific indicators for the attainment of development goals requires a painstaking process of policy-making based on scientific evidence derivable from relevant evidence. Sanni, Oluwatope, Adeyeye \& Egbetokun (2016) found that most lawmakers do not use evidence-based STI information. They also found that the use of expert opinion is one of the main sources of STI information complemented by academic journals and public opinions. Another finding was that the use of information from experts was adversely affected by the law makers' level of education, number of years spent in the committee and duration of the period as members of a committee. Siyanbola, Egbetokun, Oluseyi, Olamade, Aderemi \& Sanni (2012) found that Nigeria's indigenous technologies present significant opportunities for local economic transformation and, to some extent, global competitiveness. Guira,Some, Kabore, Sawadogo-Lingani, Traore,\& Savadogo (2017) found that cassava's utilization in processing units for products such as attiéké, gari, tapioca, flour, foufou, cossette, and other products such as starch, fermented flour, curds, etc , is widespread in Burkina Faso. None of these products is an exportable industrialized good.

Shodjai (1994) found that developing countries around the world (including Africa) faced similar challenges in not only the acquisition of science and technology but also applying these to solve the myriad of their development problems. Specifically, the researcher found that developing countries had teething problems with: Issues regarding technological capability, issues regarding transfer and assimilation of foreign technology, national R\&D (research and development) and S\&T (science and technology) infrastructure, local Research and Development (R\&D) and its relationship with the modern $R \& D$, propagation of $R \& D$ and technology within the country national policies regulating 
import of technology, developing and protecting the local technology, adapting appropriate technology to the needs of the country, the nature of science and its processes, socialization of science and its problems

A cursory look at these research findings indicates that it has not been possible for developing countries to acquire and utilize science and technology as it is done in the developed countries. At present, not much has changed from the 1994 situation and Africa cannot utilize local content materials in the manufacture of technological or other goods.At best, African countries (with exception of South Africa) can only process raw materials for export to the developed for manufacturing finished goods.

\subsection{Africans' Consumption of Locally-Made Goods}

Isah (2017) found that Nigerians were not satisfied with made-in-Nigeria goods due to low quality and publicity by the marketers. Opoku1\&Akorli (2009) found that the country of origin is more important than the price of the product as well as other product attributes. The Ghanaian consumer holds the 'Made in Ghana' label in low regard relative to foreign labels, whilst superior quality and consumer taste are the two most important reasons for the Ghanaian consumers' preference for foreign products. Domie (2013) investigated assessing the factors influencing consumer switch from local to imported products: a case study of Kasapreko Company Limited, Ghana and found that in collectivist cultures like Ghana, affordability has become an important factor. Quality, the next factor, is defined simply as freedom from defect and the ability of the product to perform what it is supposed to do. It is also described as the ability of the product to satisfy stated or implied needs (Kotler \& Keller 2006). The research found that Ghanaians place value on the aesthetics and social status of the product. Bamfo (2012) researcher found that although there was some element of ethnocentrism among respondents; they were not highly ethnocentric although the research noted that industries in the country needed to increase the quality of their products, reduce prices and make available more products to compete favorably with those imported. Razak, Nazief, \&Boge (2016) found that the functional value of the toothpaste product bought by the customer is not optimal yet to be a major consideration to satisfy the customers. Rather, it is precisely the quality of the toothpaste product itself conforming to the production standard in advance.

Based on the literature reviewed, the researchers argue that if the strategies enumerated above have failed to put / Africa on a path to growth and sustainable development, the continent is left with no other options than to follow the arguments of Guest (2004) to look inwards in a soul-searching reflection to chart its path of growth and sustainable development. Of particular interest to Africa is the outcome of the $20^{\text {th }}$ Pacific Trade and Development Conference (PAFTAD 20) that held in Washington in September, 1992. The Pacific region has burst into phenomenal economic expansion, prosperity, growth and sustainable development based on putting in place building blocks of international trade flow, the relationship between globalization and regionalism, foreign direct investment, international labour organization, trade and the environment and security among others.

\section{Methodology}

A survey design was adopted for this study because it set out to ascertain the relationship between African universities collaborative research in technological innovations, utilization of local content materials in manufacturing technological equipment and Africans' consumption of locally-made technological goods with Africa's path to growth and sustainable development. The population of the study was made up of 16,000 academic staff from six universities and one polytechnic across the continent. A sample of 480 respondents was identified through cluster sampling. A four-cluster 4point rating scale with thirty-six items was constructed and administered on the sample for data collection. Data collected were analyzed with Pearson Product-Moment Correlation at the alpha level of $p>0.05$. In order to take decisions on the results of analyses, the correlation coefficients were converted to $t$-calculated based on the formula:Cal- $\mathrm{t}=\mathrm{n}-2$ (cal$r$ ).Decision was that where calculated $t>$ table $t$; the hypothesis was rejected. Where calculated $t$ was $<$ table $t$, the hypothesis was not rejected.

\section{Results}

Null hypothesis one stated that there is no significant relationship between African universities' collaborative research in technological innovations and Africa's path to growth and sustainable development. After analyses of data, the results were as follows: the calculated $t$ value for hypothesis one was 217.356 against the table $t$ value of 4.303 at 2 dfas shown in Table 1. The null hypothesis was rejected.

\begin{tabular}{|c|c|c|c|c|c|c|}
\hline Variables & Mean & Std Dev. & DF & t-cal & p-value & Sig.value \\
\hline $\begin{array}{c}\text { African universities' collaborative } \\
\text { research in technological innovations }\end{array}$ & 34.2104 & 3.44832 & 479 & 217.356 & .05 & 0.000 \\
\hline $\begin{array}{c}\text { Africa's path to growth and } \\
\text { sustainable development }\end{array}$ & 35.5396 & 4.39711 & 479 & 177.079 & .05 & 0.000 \\
\hline
\end{tabular}

Table 1: Mean and Standard Deviation Scores of African Universities'

Collaborative Research in Technological Innovations and

Africa's Path to Growth and Sustainable Development ( $\mathrm{N}=480)$

For hypothesis two, the calculated t value was 44.355 against the table t value of 4.303 as shown in Table 2. Here, too, the null hypothesis which stated that the utilization of local content materials in the production of technological and other goods has no significant relationship with Africa's path to growth and sustainable development was rejected. 


\begin{tabular}{|c|c|c|c|c|c|c|}
\hline Variables & Mean & Std Dev. & DF & t-cal & $\begin{array}{c}\text { p- } \\
\text { value }\end{array}$ & $\begin{array}{c}\text { Sig. } \\
\text { value }\end{array}$ \\
\hline $\begin{array}{c}\text { Utilization of local content materials in } \\
\text { the production of technological and other } \\
\text { goods }\end{array}$ & 33.9146 & 3.20018 & 479 & 44.355 & 0.000 & .05 \\
\hline $\begin{array}{c}\text { Africa's path to growth and sustainable } \\
\text { development }\end{array}$ & 35.5396 & 4.39711 & 479 & 177.079 & 0.000 & .05 \\
\hline
\end{tabular}

Table 2: Mean and Standard Deviation Scores of Utilization of Local Content Materials in the Production of Technological and Other Goods and Africa's Path to Growth and Sustainable Development $(\mathrm{N}=480)$

For hypothesis three, the calculated t value was also 44.355 as shown in Table 3 . This null hypothesis which stated that Africans' consumption of locally-made goods has no significant relationship with the continent's path to growth and sustainable development was also rejected.

\begin{tabular}{|c|c|c|c|c|c|c|}
\hline Variables & Mean & Std Dev. & DF & t-cal & p-value & Sig. value \\
\hline $\begin{array}{c}\text { Africans' Consumption of Locally- } \\
\text { Made Technological Goods }\end{array}$ & 35.1917 & 17.3873 & 479 & .44 .355 & 0.00 & .05 \\
\hline $\begin{array}{c}\text { Africa's path to growth and } \\
\text { sustainable development }\end{array}$ & 35.5396 & 4.3911 & 479 & 177.079 & 0.000 & .05 \\
\hline
\end{tabular}

Table 3: Mean and Standard Deviation Scores of Africans' Consumption of Locally-Made

Goods and Africa's Path to Growth and Sustainable Development ( $\mathrm{N}=480$ )

However, for hypothesis four, there was a mixed result. The calculated t value was 177.079 against the table $t$ value of 4.303 indicated a rejection of the null hypothesis which stated that African universities' collaborative research in technological innovations, utilization of local content materials in the production of technological and other goods, Africans' consumption of locally-made technological goods and Africa's path to growth and sustainable development do not have a significant relationship but the $\mathrm{F}$ value after regressing the variables was 1.273 against the critical $\mathrm{F}$ value of 3.00. This indicated a non-rejection of the null hypothesis as shown in Table 4.

\begin{tabular}{|c|c|c|c|c|c|}
\hline Model & $\begin{array}{c}\text { Sum of } \\
\text { squares }\end{array}$ & DF & Mean Square & F & Sig. \\
\hline Regression & 73.713 & 3 & 24.571 & 1.273. & .283 \\
Residual & 9187.535 & 476 & 19.302 & & \\
\hline Total & 9261.248 & 479 & & & \\
\hline
\end{tabular}

Table 4: ANOVA Results of One-Way ANOVA of Mean and Standard Deviation Scores of African

Universities' Collaborative Research in Technological Innovations, Utilization of

Local Content Materials in the Production of Technological and Other Goods,

Africans' Consumption of Locally-Made Goods and Africa's Path to

Growth and Sustainable Development $(\mathrm{N}=480)$

Not Significant at $\mathrm{P} \varangle 0.05$ Level with $\mathrm{DF}(3,476)$ and F-Critical $=3.00$

\section{Discussion of Findings}

The rejection of the first three hypotheses implies a moderate, positive and significant relationship between African universities' collaborative research in technological innovations, utilization of local content materials in the manufacture of technological and other goods and Africans' consumption of locally-made goods and Africa's path to growth and sustainable development. This finding is supported by literature reviewed. The mixed result of hypothesis four implies that there may be other plausible factors relating to Africa's path to growth and sustainable development that were not taken into consideration during the development of the instrument for data collection. However, this does not vitiate the findings made as Appendices 2, 3 and 4show the coefficients, residual and Pearson $r$ correlation statistics on the estimated relationship between the variables.

\section{Conclusion}

Based on the literature reviewed and results of this study, the researchers conclude that there is a significant relationship between African universities' collaborative research in technological innovations, utilization of local content materials in the manufacture of technological and other goods, Africans' consumption of locally-made goods and Africa's path to growth and sustainable development.

\section{Recommendations}

The researchers, therefore, recommend that:

- Some African Universities should come together and establish a Pan-African Universities' Research Team in Technological Innovations in the continent. 
- African universities should be sensitized to give institutional support to lecturers (scientists and technologists) who become research team members of Pan-African Universities' Research Team in Technological Innovations.

- The PAURTTI, if established, should explore linkages and collaboration with industrialists and/ or industrial establishments that engage in ventures of mutual interest.

\section{References}

i. Abdulrahman, D. A. Colonialism, development paths, globalization and social inequality: the sources of social conflicts in Nigeria. In Oni, D., Gupta, S., Omoniyi, T., Adgbija \& Awonusi, S. (2008, Eds). Nigeria and globalization: discourses on identity politics and social conflict; Lagos: Center for Black and African Arts and Civilization (CBAAC).

ii. Agbo, A. O. (2012). Africa: the glory, the curse, the remedy - biblical perspectives of the African predicament; Enugu: Snaap Press Nigeria Ltd.

iii. Ahenkan, A \&Osei-Kojo, A.(2014). Achieving sustainable development in Africa: progress, challenges and prospects; International Journal of Development and Sustainability, Vol. 3, No. 1; pp.162-176.

iv. Ajayi, I. S. External debt, capital flight and growth in Nigeria. In Okonjo-Iweala, N., Soludo, C. C.\& Muhtar M. (2003, Eds). The debt trap in Nigeria: towards a sustainable debt strategy; Asmara: Africa World Press, Inc.

v. Akinbami, C. A. O., Ifeanyi-Obi, C., Appiah, D. O. \& Kabo-Bah, A. T. (2016). Towards sustainable adaptation to climate change: the role of indigenous knowledge in Nigeria and Ghana;African Journal of Sustainable Development, Vol. 6, No. 2.

vi. Almond, G.A, PowellJJ, G.B., Strom, K. and Dalton, R.J (2004). Comparative politics Today: A World View; New Delhi: Dorling Kindersley (India) Pvt Ltd.

vii. Appiah, D. O. \& Azeez, I. O. (2016). Sustaining rural livelihoods: on-farm climate-smart adaptation measures among smallholder farmers in rural Ghana; African Journal of Sustainable Development, Vol. 6, No. 2.

viii. Ashimolowo, M. (2007). What is wrong with being black? Celebrating our heritage, confronting our challenges; Shippensburg: Destiny Image \& Publishers, Inc.

ix. Awe, K. O., Olawale, S. \& Bola, T. (2016). Strategic corporate ventures for competitiveness and sustainable development in Nigeria; International Journal of Operational Research in Management, Social Sciences and Education, Vol. 2, No. 1; pp.75-82.

x. Bamfo,B. A. (2012). Consumer attitude toward products madeIn Ghana; Global Journal of Business Research, Volume 6, Number 1; pp. 38-46.

xi. Bengstein, C. F. \& Norland, M. (1993). Pacific dynamism and the international economic system; Washington, D. C.: Institute for International Economics.

xii. Bogoro, S. E. (2015). Enhancing the relevance of research and industry partnership in Nigeria: a case for new strategies; Convocation Lecture; Owerri: Federal University of Technology (FUTO).

xiii. Bremer, M. H. \& López-Franco, R. (2006). Sustainable development: ten years of experience at ITESM's graduate level. Journal of Cleaner ProductionVolume 14, Issues 9-11, pp. 952-957. https:/ / doi.org/ 10.1016/j.jclepro.2005.11.039.

xiv. Chukwumezie, F. U., Osakpa, D. U. \& Okonkwo, Dyke A. R. (2016). Business management strategies, capital formation and sustainable development in the $21^{\text {st }}$ century and beyond; Education and Science Journal of Policy Review and Curriculum Development, Vol. 6, No. 1; pp. 32-43.

xv. Clarke, D. (2008). Africa: crude continent - the struggle for Africa's oil prize; London: Profile Books Ltd

xvi. Collier, P. International experience of aid and debt strategies: implications for Nigeria. In Okonjo-Iweala, N., Soludo, C. C.\& Muhtar, M. (2003, Eds). The debt trap in Nigeria: towards a sustainable debt strategy; Asmara: Africa World Press, Inc.

xvii. Domfeh, K. A., Ahenkan, A \& Bawole, J. N. (2012). Is sustainable development achievable in Ghana?An analysis of Ghana's development policyachievements and challenges; Int. Journal of Environment and Sustainable Development, Vol. 11, No. 3,pp.304-317.

xviii. Domie, S. P. (2013). Assessing the factors influencing consumer switch from local to imported products: a case study of Kasapreko Company Limited, Ghana; Unpublished Degree Project: Vaasa: Vaasan Ammattikorkeokoulu Vasa Yrkeskogskola University of Applied Sciences.

xix. dos Santos, T. The structure of dependence. In Seligson, M. A. \& Passe-Smith, J. T. (1993, Eds). Development and underdevelopment: the political economy of inequality; London: Lynne Riuenner Publishers, Inc.

xx. Enweze, C. Sustainable debt and development strategy in Africa. In Okonjo-Iweala, N.,Soludo. C. C.\& Muhtar, M. (2003, Eds). The debt trap in Nigeria: towards a sustainable debt strategy; Asmara: Africa World Press, Inc.

xxi. Esteves, A. M., Coyne, B. \&Moreno, A. (2013). Local content initiatives: enhancing the sub-national benefits of the oil, gas and mining sectors; Briefing: Natural Resource Governance Institute.

xxii. Fari, S. A. (2013). Research collaboration among academics in selected Universities in Nigeria and South Africa; The Information Technologist; Vol. 12, No. 1; pp. 32-47.

xxiii. Forsyth, F. (1977). The making of an African legend: the Biafra story; Suffolk: Richard Clay; The Chaucer Press Ltd.

xxiv. Garba, J. (1987). Diplomatic soldiering: the conduct of Nigerian foreign policy (1975-1979). Ibadan: Spectrum Books Ltd.

xxv. Guest, R. (2005). The shackled continent; London: Pan Books. 
xxvi. Guira, F.,Some,K., Kabore,D., Sawadogo-Lingani,H., Traore,Y. \&Savadogo, A. (2017). Origins, production, and utilization of cassava in Burkina Faso, a contribution of a neglected crop to household food security. Food Science and Nutrition. 5(3):pp. 415-423. doi: 10.1002/ fsn3.408

xxvii. Hammajam, A. A., Mairo, A. W. \& Usman, I. (2016). Innovation as a critical factor: a case study about the partnership among Polytechnics with industry in Nigeria; Education and Science Journal of Policy Review and Curriculum Development; Vol.6, No.1; pp.44-50.

xxviii. Igwe, S. C. (2010). How Africans underdeveloped Africa; Port Harcourt: Professional Printers and

xxix. Publishers.

xxx. Kotler, P. and Keller, K. (2006) Marketing Management. 12th Edition, Prentice Hall, Upper Saddle

xxxi. River.

xxxii. Lundvall, B. \& Lema, A. (2014). Growth and structural change in / Africa: development strategies for the learning economy; African Journal of Science, Technology, Innovation and Development; Vol. 6, Issue 5; pp.455-466.

xxxiii. Makoni, M. (2011). Global: French-speaking universities collaborate. Issue No. 75; University World News: Africa Edition

xxxiv. Mensah, M. S. B., Enu-Kwesi, F \& Boohene, R. (2017). Challenges of Research Collaboration in Ghana's Knowledgebased Economy; Journal of the Knowledge Economy, pp.1-19.https:/ link.springer.com/ article/ 10.1007/ s13132017-0450-8

xxxv. Meredith, M. (2011). The state of Africa: a history of the continent since independence; London: Simon \& Schuster UK Ltd.

xxxvi. Morris, I. (2011). Why the West Rules - For Now: The patterns of history and whatthey reveal about the future; London: Profile Books.

xxxvii. Morrison, P. S., Dobbie, G. \&McDonald, F. J. (2013). Research collaboration among university scientists; Journal of Higher Education Research and Development; Vol. 22, Issue 3; pp.275-296

xxxviii. Ngwenya, B. (2014). Universities, Tertiary Institutions and their Role in PPP Initiatives; Sunday News Online.Bulawayo.

xxxix. Norton A. \&Rogerson, A. (2012). Inclusive and sustainable development: challenges, opportunities, policies and partnerships; Danida: International Development Cooperation - Ministry of Foreign Affairs, Denmark.

xl. Nwankwo, S., Chaharbaghi, K. \& Boyd, D. (2009). Sustainable development in sub-Saharan Africa: Issues of knowledge development and agenda setting, International Journal of Development Issues, Vol. 8 Issue: 2, pp.119133, https:/ / doi.org/ 10.1108/ 14468950910997684

xli. Obanor, A. I. \& Kwasi-Effah, C. C. (2013). Assessment of universities-industries collaboration and technology transfer in schools of engineering and sciences in Nigeria.Nigerian Journal of Technology (NIJOTECH)Vol. 32. No. 2., pp. $286-293$

xlii. Okonkwo, Dyke A. R., Ejiogu, S. I. \& Osakpa, D. U. (2017). Ending Africa's dependency on developed countries: the intellectual capital-knowledge economy option; International Journal of Innovative Research in Education, Technology and Social Strategies, Vo. 4, No. 2; pp.76-89.

xliii. Opoku, R. A. \&Akorli, P. A. K. (2009). The preference gap: Ghanaian consumers' attitudestoward local and imported products; African Journal of Business Management Vol. 3 (8), pp. 350-357. DOI: 10.5897/ AJBM09.085.

xliv. Opolot-Okurut, C., \& Bbuye, J. (2014). School-University Collaboration Initiative: Benefits and Challenges in Uganda; American Journal of Educational Research2, 10; pp.843-849.

xlv. PAFTAD 20; 20th Pacific Trade and Development Conference; Washington: September, 1992.

xlvi. Peacock, H. L. (1982). A history of modern Europe (1789-1981); London: Heinemann Educational Books.

xlvii. Pingijian, Z. (2018). Blatant trade bullying will only backfire. Daily Sun, Wednesday, August 1; p.16. The Sun Publishing Limited.

xlviii. Protsiv, M., Rosales-Klintz, S., Bwanga, F., Zwarenste in, M. \&Atkins, S. (2016). Blended learning across universities in a South-North-South collaboration: a case study; Health Research Policy and Systems, 14:67;https:/ / doi.org/ 10.1186/ s12961-016-0136-x

xlix. Raheem, I. D., Isah, K. O. \& Adedeji, A. A. (2018).Inclusive growth, human capital development and natural resource rent in Sub-Saharan Africa: Economic Change and Restructuring, Springer, Vol. 51(1), pp. 29-48, Handle: ePEc:kap:ecopln:v:51:y:2018:1:1:d:10.1007 s10644-016-9193-yDOI: 10.1007/ s10644-016-9193-y

l. Razak, I., Nazief, N. \& Boge, T. (2016). The Impact of Product Quality and Price on Customer Satisfaction with the Mediator of Customer Value; Journal of Marketing and Consumer Research; Vol.30. pp.59-68. ISSN 2422-8451

li. Rodney, W. (1972). How Europe underdeveloped Africa; Washington, D. C.: Howard University Press.

lii. Sanni, M., Oluwatope, O., Adeyeye, A.Egbetokun, A. A. (2016). Evaluation of the Quality of Science, Technology and Innovation Advice Available to Lawmakers in Nigeria; Palgrave Communications, Vol. 2, 2016

liii. Shodjai, F. (1994). Science and Technology Policy in Developing Countries with Special Emphasis on Latin America--An Annotated Bibliography: Washington, D.C.: Centre for Policy Research on Science and Technology; Simon Fraser University. shodjai@sfu.ca

liv. Siyanbola, W.O, Adeyeye, A., ,Olaopa, O. \&Hassan, O. (2016). Science, technology and innovation indicators in policy-making: the Nigerian experience; Palgrave Communications,

lv. Volume 2, Article number: 16015

lvi. Siyanbola, W. O., Egbetokun, A. A., Oluseyi, I., Olamade, O. O/ . Aderemi, O. H. \&, Sanni, M. (2012). Indigenous Technologies and Innovation in Nigeria: Opportunities for SMEs; American Journal of Industrial and Business Management, 2012, 2, 64-75; 
lvii. http:/ / dx.doi.org/ 10.4236/ ajibm.2012.22009

lviii. Stem, P.C. (2000). Toward a coherent theory of environmentally significant behavior. Journal of Social Issues, Vol. $56, \mathrm{pp} 407-424$.

lix. Udeozor, R. K. \& Mbagwu, L. I. (2012). Role of creativity, innovation and strategic planning in enhancing entrepreneurship in Nigerian organizations. Abuja International Journal of Education and Management Sciences, Vol. 1, No. 2; pp.313-329.

lx. William, O. \& William, S. (1999). The impact of foreign direct investment flows to the Eastern Caribbean Central Bank Unified Currency Area; Quarterly Review, No. 2; pp.131-144.

\section{Appendix}

\begin{tabular}{|c|c|c|c|}
\hline Serial No. & Institution & Population & Sample \\
\hline 1 & Kampala International University, Western Campus, Uganda & 5,350 & 80 \\
\hline 2 & University of Calabar, Calabar, Nigeria & 4,120 & 80 \\
\hline 3 & Cross River University of Technology, Calabar & 1,650 & 80 \\
\hline 4 & Imo State University, Owerri, Nigeria & 1,430 & 80 \\
\hline 5 & African University College of Communications, Accra, Ghana & 130 & 30 \\
6 & University of Ghana, Legon & 1500 & 50 \\
7 & Federal Polytechnic, Nekede, Owerri, Nigeria & 800 & 80 \\
\hline & Total & 15000 & 480 \\
\hline
\end{tabular}

Table 5: Population and Sample Distribution by Institutions

Coefficients of Model equation predicting estimated relationship between African universities' collaborative research efforts in technological innovations, utilization of local content materials in the production of technological goods,Africans' consumption of locally-made goods and Africa' path to growth and sustainable development $(\mathrm{n}=480)$

\begin{tabular}{|c|c|c|c|c|c|}
\hline $\begin{array}{c}\text { Model } \\
\text { Components }\end{array}$ & $\begin{array}{c}\text { Un-Standardized } \\
\text { Coefficients }\end{array}$ & $\begin{array}{c}\text { Standardized } \\
\text { Error }\end{array}$ & $\begin{array}{c}\text { Standardized } \\
\text { Coefficients }\end{array}$ & $\begin{array}{c}\text { T-Calculated } \\
\text { Value }\end{array}$ & Sig. \\
\hline Constant & 36.373 & 2.668 & & 13.634 & .000 \\
AUCRTI & .061 & 0.060 & 0.40 & 1.019 & .309 \\
ULCMPTOG & -.098 & 0.064 & -.072 & -1.527 & .127 \\
ACLMG & 0.012 & 0.012 & 0.46 & .999 & .318 \\
& & & & & \\
\hline
\end{tabular}

Table 6: Coefficients of Model Equation Predicting Estimated Relationship between the Variables Significant atP $<0.05$; critical $t=1.64$

Residual statistics of the Model equation predicting the estimated relationship between African universities' collaborative research in technological innovations, utilization of local content materials in the production of technological goods, Africans' consumption of locally-made goods and Africa's path to growth and sustainable development $(\mathrm{n}=480)$

\begin{tabular}{|c|c|c|c|c|c|}
\hline Model & Minimum & Maximum & Mean & Std Deviation & Total N \\
\hline Predicted value & 34.6032 & 39.6772 & 35.5396 & .39229 & 480 \\
Residual & -16.53590 & 4.64898 & 0000 & 4.37157 & 480 \\
Std. Residual & -3.783 & 1.058 & 0000 & -4.37957 & \\
\hline
\end{tabular}

Table 7: Dependent Variable: Africa's Path to Growth and Sustainable Development

\begin{tabular}{|c|c|c|c|c|c|}
\hline & & APGSD & AUCRTI & ULCMPTOG & ACLMG \\
\hline Pearson Correlations & APGSD & 1.000 & .040 & -.056 & .044 \\
\hline & AUCTRI & .040 & 1.000 & .201 & .144 \\
\hline & ULCMPTOG & .056 & .201 & 1.000 & .129 \\
\hline & ACLMG & .044 & .144 & .129 & 1.000 \\
\hline Sig. (1-tailed) & APGSD & & .190 & .111 & .168 \\
\hline & AUCTRI & .190 & & .000 & .001 \\
\hline & ULCMPTOG & .111 & .000 & & .002 \\
\hline & ACLMG & .168 & .001 & .002 & \\
\hline $\mathrm{N}$ & APGSD & 480 & 480 & 480 & 480 \\
\hline & AUCTRI & 480 & 480 & 480 & 480 \\
\hline & ULCMPTOG & 480 & 480 & 480 & 480 \\
\hline & ACLMG & 480 & 480 & 480 & 480 \\
\hline
\end{tabular}

Table 8: Pearson r Correlations 
From the entries in Tables 4, 5 and 6, the prediction equation for this model could be constructed under the assumption that the relationship among the variables in the study is linear and hence:

$\mathrm{Y}=\mathrm{A}+\mathrm{B}_{1} \mathrm{X}_{1}+\mathrm{B}_{2} \mathrm{X}_{2}+\mathrm{B}_{3} \mathrm{X}_{3}$

Where, $Y=$ dependent variable (Africa's path to Sustainable growth and development)

$\mathrm{A}=$ the Constant of the model as applicable in linear regression models;

$\mathrm{B}_{1} \mathrm{X}_{1}$ the Coefficient and the Mean value the variable (AUCRTI);

$\mathrm{B}_{2} \mathrm{X}_{2}$ the Coefficient and the Mean value the variable (ULCMPTOG);

$\mathrm{B}_{3} \mathrm{X}_{3}$ the Coefficient and the Mean value the variable (ACLMG) 